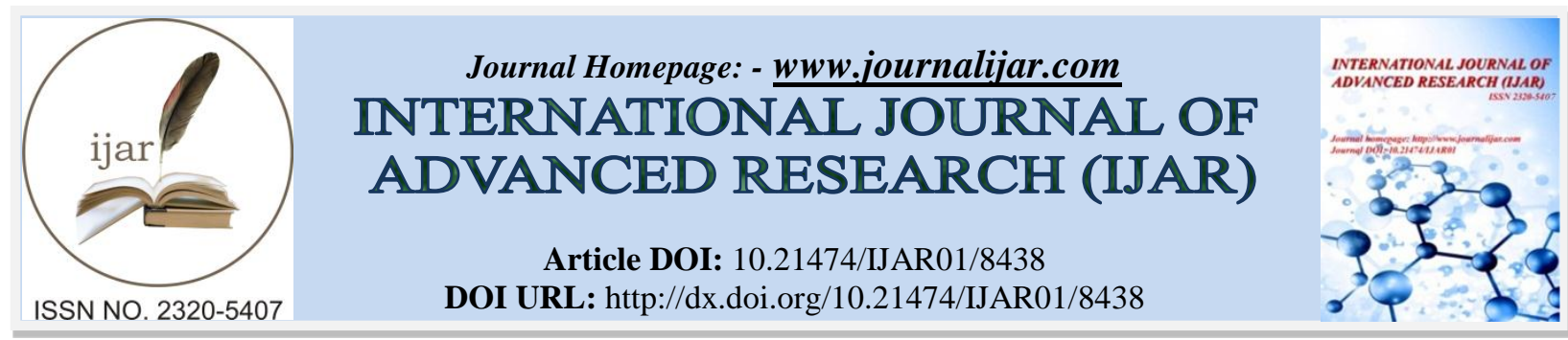

RESEARCH ARTICLE

\title{
PHYSIOLOGY AND MANAGEMENT OF NORMAL PUERPERIUM THROUGH AYURVEDA.
}

\section{Punam Kumari ${ }^{1}$ and Rashmi Sharma ${ }^{2}$.}

1. PG Scholar, PG Department of Prasuti tantra and stree roga Department, Dr. S. R. Rajasthan Ayurved University Jodhpur, Rajasthan.

2. M.S. (Ayu), Assi. Prof. PG Department of Prasuti tantra and stree roga Department, Dr. S. R. Rajasthan Ayurved University Jodhpur, Rajasthan.

\section{Manuscript Info}

\section{Manuscript History}

Received: 20 November 2018

Final Accepted: 22 December 2018

Published: January 2019

Key words:-

Ayurveda, Puerperal physiology, Sutika paricharya.

\begin{abstract}
Ayurveda give importance for the care of mother at every phase of her life especially when it comes to postnatal care. A puerperal period begins immediately after the separation of placenta and extending up to 6 weeks. Remarkable changes take place during the puerperium, which enable the women's body to revert to the non pregnant state. In Ayurvedic classics it correlated with "Sutika Paricharya", as during this period she restores her health and strength. In this stage mother should be educated to take care of herself and the new born baby. Therefore she needs special and proper care during puerperium. Acharyas have described Ashwasana (Psycological Reassurance), Aahara (Normal diet in puerperium) and Vihara, Ashwasana (Psycological Reassurance) in Sutika Paricharya. Ayurveda also prescribes numerous herbs to establish healthy status of the women after delivery.
\end{abstract}

Copy Right, IJAR, 2018,. All rights reserved.

\section{Introduction:-}

A women has just given birth to a baby along with placenta is called "Sutika" in Ayurveda \& "Puerperal Women" in Modern science. Thus the word, puerperal means to give birth to a child and puerperium is the period from the termination of labour to complete involution of the uterus usually as 42 days or 6 weeks. Motherhood is the most sacred and greatest boon that god has best wed upon a women. A woman becomes a complete woman when she becomes a mother. The first 6 weeks after the birth of the baby is known as postpartum period or puerperium. During this time, mothers experience numerous physiological and psychological changes. Main changes occur for uterus is involution of the uterus and descent of the fundus. Involution begins immediately after the delivery of the placenta. The term involution refers to retrogressive changes taking place in all organs and structure of the reproductive tract. Involution of uterus is the process where uterus returns to non pregnant state after the birth of baby. Almost all samhitas, Acharyas have mentioned the specific management of sutika only after the expulsion of placenta. The woman becomes weak or emaciated due to development of fetus and also empty bodied due to unsteadiness or languor of all the dhatus, labour pains and excretion of kleda (moisture) and blood . With Ayurvedic management, she attains all the lost things and reaches her pre-pregnant state.

\section{Corresponding Author:-Punam Kumari.}

Address:-PG Scholar, PG Department of Prasuti tantra and stree roga Department, Dr. S. R.

Rajasthan Ayurved University Jodhpur, Rajasthan. 


\section{Definition of Sutika}

Acharya Kashyapa said Sutika term can be used only after expulsion of placenta. Here Acharya clearly mentions that after delivery of an infant, till the placenta is not expelled, the women cannot be called sutika. In other words sutika term can be used only after expulsion of placenta.

\section{Sutika Kala}

Acharya Charaka has not mentioned any exact time. However, all other classics have given definite duration for specific management of puerperium, which can be considered as normal duration of puerperium. Acharya Sushruta has very nicely described the duration of sutika kala (puerperal period) for a period of 11/2 month. In other words puerperal women should adopt restrictions regarding diet and body movements till she gets regular menstrual cycles

Acharya Kashyapa has narrated Sutika Kala in two ways. He is not mentioning any exact time limit, but at the end of the description of paricharya he has advised to follow it up to one month and afterwards he mentions that within 6 months after the delivery, Sutika regains all the dhatus, rakta etc. and reaches up to her natural and normal form . In Ayurvedic texts physiological changes during puerperium has described very well then the anatomical changes. Acharya Vriddha Vagbhatta, Vagbhatta, Bhava Mishra. have followed the description given by Acharya Sushruta.

\section{Involution of the uterus}

\section{Pysiological consideration}

The physiological process of involution is most marked in the body of the uterus.

\section{Changes occur in the following components:}

1. Muscles

2. Blood vessels

3. Endometrium

\section{Muscles:}

1. During puerperium, the number of muscle fibers is not decreased but there is substantial reduction of the myometrial cell size.

2. Withdrawal of the steroid hormones, estrogen and progesterone, may lead to increase in the activity of the uterine collagenase and the release of proteolytic enzyme.

\section{Blood vessels:}

1. The changes of the blood vessels are pronounced at the placental site. The arteries are constricted by contraction of its wall and thickening of the intima followed by thrombosis.

2. New blood vessels grow inside the thrombi.

\section{Endometrium:}

1. The superficial part containing the degenerated decidua, blood cells and bits of fetal membranes becomes necrotic and is cast off in the lochia.

2. By the $10^{\text {th }}$ day regeneration of the epithelium is completed.

3. By the $16^{\text {th }}$ day the endometrium is restored.

4. At about 6 weeks the endometrium of placental site is restored.

\section{Involution of vagina}

1. The distensible vagina, noticed soon after birth takes a long time (4-8 weeks) to involute.

2. It regains its tone but never to the virginal state.

3. Hymen is lacerated and is represented by nodular tags — the carunculae myrtiformes.

\section{Lochia}

1. It is the vaginal discharge for the first fortnight during puerperium.

2. The discharge originates from the uterine body, cervix and vagina.

3. Odor and reaction: It has got a peculiar offensive fishy smell. 


\section{Color:}

Depending upon the variation of the color of the discharge, (1) Lochia rubra ( 1-4 days) in red color, (2) Lochia serosa (5-9 days) the color is yellowish or pink or pale brownish, (3) Lochia alba 10-15 days) pale

White color.

\section{Amount:}

The average amount of discharge for the first 5-6 days, is estimated to be $250 \mathrm{ml}$.

\section{Normal duration:}

The normal duration may extend up to 3 weeks.

\section{Clinical importance:}

The character of the lochial discharge gives useful information about the abnormal puerperal state. The vulval pads are to be inspected daily to get information about odor, amount, color, duration of lochia.

\section{Aims of sutika paricharya}

1. To restore the dhatus.

2. To restore the exhaustion of labour.

3. To heal laceration in the external genital organ.

4. To dis - infect the birth canal.

5. To provide the better milk quality to the newborn.

6. To take care of breasts including promotion of breast feeding.

7. To provide for care of the baby.

8. To motivate and guide for family planning.

9. To give need based health education.

\section{Sutika Paricharya}

The term "Sutika Paricharya" is composed of two separate words , Sutika+Paricharya according to general grammatical ideology. The term give a meaning of nurshing or management of Sutika is described by all of our Acharyas in the Ayurvedic science under the caption of 'Sutika Paricharya.In general, all the classics have advised massage, oral administration of fats with medicines and use of medicines and decoctions for three to seven days after delivery. Medicated rice gruel is prescribed in diet from seventh or twelfth day of delivery. Medicated meat soup is also advised. However, there is slight difference of opinion in the list of drugs amongst various authors. Acharya Charaka says that when sutika feels hungry she should be prescribed powdered Pippali (Piper longum), Pippalimula (Piper longum), Cavya (Piper retrofractum vahl.), Citraka (Plumba gozeylanic), and Srngabera (Zingiber officinale) with any one out of Ghrita, oil Vasa (animal fat) or Majja (marrow) considering her tolerability for these edibles and in the quantity which she can digest easily. Charak also recommends abdomen massage of sutika. After massage the abdomen should be wrapped properly with big clean cotton cloth. This wrapping produces compression of abdomen, thus prevents presence of hallow space, so the vayu does not get vitiated. Liquid gruel made with rice and medicated with Pippali (Piper longum), etc. mentioned above and mixed with ghrita should be given during both the times i.e. morning and evening. Irrigation bath with hot water should proceed. Acharya Cakrapani says that the morning irrigation should be given before digestion of oleaginous substance afterward rice gruel should be given. After use of this regimen for five or seven days, gradual administration of vrmhana substances (anabolic or likely to increase flesh and energy) should be done. This regimen is not suitable for the women of Anupadesa (marshy land), because in the residents of this area, the kapha is dominant. This regimen is suitable for the women of jangala (Wild ordry) area .

\section{Benefits of Sutika Paricharya}

In sutika kala, proper sutikaparicharya enhances complete involution of uterus and other pelvic organs, so that they reach to their pre pregnant state.

\section{Pathya \& Apathya for Sutika}

In Sutika kala, vitiation of vata is very much possible due to less activity of sutika. Even less consumption of vatala diet in a small quantity may create many problems. So pathya and apathya of the sutika should be understood. 


\section{Pathya}

Pathya (wholesome) is that which is not harmful to pathya (of the body) and is according to liking. Sutika should be advised to follow the following pathyas 26

\section{Pathya Aahar}

1. Boiled water should be taken for drinking purpose.

2. Diet and drinking items should be prepared with jeevaniya and Brimhaniya drugs.

3. She should always take snigdha (unctuous) diet.

4. Whatever the diet sutika takes must be in lesser quantity than her routine diet.

\section{Pathya Vihar}

1. Sutika should have the bath with much quantity of warm water.

2. Parisheka, Avagahana is always beneficial for sutika.

3. She should be done udaravestana.

4. Snehana and swedana must be done every day as per desha, kala, etc.

\section{Apathya}

Apathy is that which is harmful to pathya (of the body) and is not according to liking (which is certainly not at all desirable). The puerperal women should be advised to avoid the following:

1. The sexual intercourse.

2. Physical stress, anger and indulgence in irresistible emotion.

3. Heat and its preparation at least up to 12 days.

\section{Conclusion:-}

Motherhood is the most sacred and greatest boon that god has best wed upon a woman. God has specially gifted proud of mother hood to a women, importance of sutika and sutika paricharya is more than other diseases of women. The post-delivery period is a very crucial phase in a woman's life. Ignorance about proper care, excessive concern about the child, and an inability to cope with motherhood may lead to post natal disorders and even depression. The Ayurvedic system of medicine describes Sutika Paricharya - a complete health regimen for the post natal woman. The management of puerperium consists of providing the means whereby the woman can recuperate physically and emotionally and gain supervised experience in the care of her infant. By using Ayurvedic and herbal medicines you ensure physical and mental health without side effects. All these methods help the body to combat the stress felt during pregnancy and labour and to regain and restore its physiological and anatomical state. There are so many thing could happen in puerperal period that influence mother's mortality rate. So, the early and correct puerperium care is important. Ayurvedic treatment is non-invasive and non-toxic, so it can be used safely as an alternative therapy or alongside conventional therapies. Now Ayurveda needs Standardization for Herbal Formulations and more works need on the sutika management in Ayurveda.

\section{Referances:-}

1. Pandit Kashinath Shastri \& Dr.Gorakhnath Chturvedi, "Vidyotiny-Hindi commentary" on "Charak samhita", 8 th chapter Sharir sthan ,Chaukhambha Bharati Academy(2011).

2. Research Article in "International Journal Home science".

3. Shastri Aambikadutta Sushruta Samhita, Purvardha Chaukhambha Publication Chikitsa sthanum chapter-15 ${ }^{\text {th }}$ Ayurvediya Prasuti tantra Evam Stree roga by Prof P. V. Tewari II I $^{\text {st }}$ Part, $\quad$ Chaukhambha, Varanasi, $2^{\text {nd }}$ Ed;Reprint-2012.

4. Laxmipati Shastri "Yogratanakar" with vidyotini”Hindi Commentry" chaukhambha Publication Varanasi,"Shtree roga Chikitsa adhayay".

5. "Kashyapa Samhita" commentary by Pandit Hemaraja Sharma Khil Sathan $11^{\text {th }}$ chapter,Chaukhambha Sanskrit Sansthan, Varanasi, 2006.

6. Textbook of Obstetrics by D.C. Dutta, 6th Ed. 2013

7. Hindi commentary by Atridev Gupta, "Astang Sangraha" Part $1^{\text {st }}$, Sharir Sathan Chapter $4^{\text {th }}$ Nirnaya sagara press, Bombay $1^{\text {st }}$ Ed.

8. "Astanga Hrdaya" , Hindi commentary by Lal Chandra Vaidya,Motilal Benarasi Dass, Sharir Sathan Chapter $2^{\text {th }}$ Varanasi,19 $631^{\text {st }}$ Ed.

9. “ Bhawaprakasa",Vidyotini Hindi commentary by Shri Brahm Sankara Misra, Chikitsa sthanum chapter-70 ${ }^{\text {th }}$, Chaukhambha Sanskrit series office Varanasi, Part $1^{\text {st }} 5^{\text {th }}$ Ed.19 69.

10. Charak samhita,with Ayurvedadipika commentary of Chakrapanidatta, "vidyotini" commentary by pandit Kashinaath sastri ,Chaukhambha Sanskrit series office, Varanasi Part $1^{\text {st }}$. 